\title{
Analisis Kebutuhan Robot Rehabilitasi Pasien Pasca Stroke dengan Menggunakan Metode Kano
}

\author{
Hasan Mastrisiswadi ${ }^{1}$ Herianto $^{2}$
}

\begin{abstract}
Product developments of post stroke rehabilitation robot have being done either by local universities or by foreign ones. In this development processes, customer needs were identified prior to the use of QFD method, assuming that improved performance of customer needs linearly affects satisfaction level. This assumption frequently does not fit real condition in the market, wherein customer satisfaction on certain needs dramatically increases by an improvement on their performance and, on the other hand, improved performance on other needs does not affect customer satisfaction at all. In this research, we conclude that almost all of attributes under study belong to onedimentional categories. Exceptions are associated with portable attribute that belong to must-be categoris and moveable attribute that belong to attractive categories. Moreover, price attribute will affect consumer satisfaction the most given it is fullfilled and control attribute will influence customer dissatisfaction the most if it is not fullfilled.
\end{abstract}

Keywords. need analysis, post-stroke, rehabilitation robot, Kano model.

\begin{abstract}
Abstrak. Pengembangan produk robot rehabilitasi pasien pasca stroke telah banyak dilakukan baik dari universitas dalam maupun luar negeri. Dalam pengembangannya, identifikasi kebutuhan telah dilakukan sebelumnya menggunakan metode QFD yang berasumsi bahwa hubungan antara peningkatan performansi terhadap kebutuhan pelanggan akan berbanding lurus dengan tingkat kepuasannya. Hal ini tidak sesuai dengan kondisi nyata di pasar, ada kebutuhan konsumen yang bila ditingkatkan performansinya akan meningkatkan kepuasannya secara signifikan, ada pula yang bahkan hampir tidak berpengaruh terhadap kepuasannya. Dalam penelitian ini didapat bahwa hampir sетиа atribut termasuk dalam kategori one dimensional, kecuali robot mudah dipindahkan (portable) yang masuk dalam kategori must be dan robot dapat digunakan dimana saja yang termasuk dalam kategori attractive. Selain itu, atribut harga yang terjangkau merupakan atribut yang mempengaruhi tingkat kepuasan tertinggi konsumen, bila atribut tersebut terpenuhi. Atribut kontrol robot yang mudah merupakan atribut yang mempengaruhi tingkat ketidakpuasan tertinggi konsumen, bila atribut ini tidak dipenuhi.
\end{abstract}

Kata Kunci. analisis kebutuhan, robot rehabilitasi, pasca stroke, model Kano.

\section{Pendahuluan}

Kebutuhan terhadap alat kesehatan tiap tahun terus meningkat, tidak terkecuali alat kesehatan untuk rehabilitasi pasien pasca stroke. Peningkatan tidak hanya terjadi terhadap kuantitas tetapi juga kualitas. Beragam teknologi

\footnotetext{
${ }^{1}$ Hasan Mastrisiswadi, Jurusan Teknik Industri, Fakultas Teknik, Universitas Dian Nuswantoro, Jl. Nakula 1 No. 5 11, Semarang.(e-mail: hasanpahlawan@gmail.com)

${ }^{2}$ Herianto, Jurusan Teknik Mesin dan Industri, Fakultas Teknik, Universitas Gadjah Mada, Jl. Grafika No. 2, Yogyakarta. (e-mail: herianto@ugm.ac.id)
}

Diajukan: 11-08-2016 Disetujui: 20-12-2016 mulai dikembangkan guna mendapatkan alat rehabilitasi yang efektif untuk digunakan, salah satunya adalah robot rehabilitasi pasien pasca stroke. Robot rehabilitasi ini sedang dikembangkan oleh banyak universitas, baik dalam negeri maupun luar negeri, termasuk juga Universitas Gadjah Mada (Bashar, 2013; Munandar, 2013; Putra, 2015; Rachman, 2014; Sadhewa, 2014; Saryanto, 2013; Subhi, 2015; Suwardi, 2015; Wahyudi, 2013; Zihni, 2014).

Pengembangan robot rehabilitasi pasien pasca stroke yang dibuat oleh Universitas Gadjah Mada ini sebelumnya telah diujikan ke pasien untuk diidentifikasi kebutuhannya (Mastrisiswadi dan Herianto, 2016) dengan menggunakan metode quality function deployment (QFD). Metode QFD dianggap mampu untuk mengidentifikasi kebutuhan pelanggan dengan baik dan dapat 
mengevaluasinya secara sistematis. Namun demikian, QFD masih dinilai kurang dalam merepresentasikan keadaan di pasar yang sesungguhnya, karena berasumsi bahwa kebutuhan pelanggan bersifat linier. Artinya peningkatan terhadap performansi kebutuhan pelanggan akan berdampak linier terhadap tingkat kepuasannya. Hal ini tidak sesuai dengan kenyataan di pasar, ada kebutuhan pelanggan yang dapat meningkatkan kepuasan pelanggan secara signifikan, ada pula yang bahkan hampir tidak memberikan dampak terhadap kepuasan pelanggan tersebut. Penentuan hubungan ini biasa dilakukan dengan menggunakan model Kano.

Artikel ini menganalisis kebutuhan robot rehabilitasi pasien pasca stroke yang sedang dikembangkan Universitas Gadjah Mada untuk melengkapi penelitian sebelumnya. Dengan demikian akan didapatkan masukan yang lebih baik terhadap produk tersebut sehingga dapat diterima oleh pasar dengan baik.

\section{Model Kano}

Menurut Cohen (1995), model Kano membagi karakteristik produk menjadi tiga kategori, dimana masing-masing kategori memberikan pengaruh terhadap konsumen dengan cara yang berbeda. Ketiga kategori tersebut yaitu:

1. Dissatisfiers, sering juga disebut karakteristik must-be, basic, atau expected. Dissatisfiers adalah karakteristik produk yang konsumen akan menerima begitu saja bila ada, dan akan menyebabkan ketidakpuasan ketika tidak ada. Dissatisfiers merupakan sesuatu yang konsumen tidak biasa menanyakan, karena mereka berekspektasi bahwa karakteristik produk tersebut pasti sudah ada di dalam suatu produk. Bila kita memberikan produk atau jasa yang memiliki banyak dissatisfiers, konsumen akan sangat tidak senang. Kita akan mendapatkan konsumen yang senang apabila kita dapat mengeliminasi dissatisfier tersebut. Akan tetapi, jika kita mengeliminasi semuanya, kita tidak akan dapat meraih kepuasan pelanggan dengan level yang sangat tinggi. Konsumen sulit mengetahui semua usaha yang dilakukan untuk mengeliminasi dissatisfiers dan mereka mulai memperhatikan aspek lain dari produk dan jasa.

2. Satisfiers, disebut juga one-dimensional, atau straight-line. Satisfiers adalah sesuatu yang konsumen inginkan ada dalam produk mereka, dan biasanya ditanyakan. Semakin kita menyediakan satisfiers, konsumen akan semakin senang. Satisfiers sering juga disebut desired quality, karena merepresentasikan aspek-aspek produk yang mendefinisikannya untuk konsumen. Contoh dari satisfiers ini antara lain kapasitas yang meningkat, biaya yang lebih rendah, reliability yang lebih tinggi, kecepatan yang lebih besar, dan penggunaan yang lebih mudah.

Tabel 1. Dissatisfiers dan related customer needs (Cohen, 1995)

\begin{tabular}{ll}
\hline Expected quality & Dissatisfiers \\
\hline $\begin{array}{l}\text { Permukaan yang halus } \\
\text { Semua bagian bekerja }\end{array}$ & Ada goresan \\
Ada bagian yang rusak \\
$\begin{array}{l}\text { Ada instruksi } \\
\text { penggunaan pada produk }\end{array}$ & $\begin{array}{l}\text { Tidak ada buku } \\
\text { intruksi }\end{array}$ \\
$\begin{array}{l}\text { Produk dengan tipe ini } \\
\text { biasanya dapat } \\
\text { melakukan fungsi X }\end{array}$ & $\begin{array}{l}\text { Fungsi X tidak ada } \\
\text { dalam produk ini }\end{array}$ \\
$\begin{array}{l}\text { Produk ini aman } \\
\text { digunakan }\end{array}$ & $\begin{array}{l}\text { Produk tidak aman } \\
\text { digunakan }\end{array}$ \\
$\begin{array}{l}\text { Produk sesuai dengan } \\
\text { standar lokal }\end{array}$ & Produk tidak sesuai \\
\hline
\end{tabular}

Tabel 2. Contoh desired quality (Cohen, 1995)

\begin{tabular}{lll}
\hline $\begin{array}{c}\text { Desired } \\
\text { quality }\end{array}$ & $\begin{array}{c}\text { Performance } \\
\text { measurement }\end{array}$ & $\begin{array}{c}\text { Direction of } \\
\text { goodness }\end{array}$ \\
\hline Kapasitas & $\begin{array}{l}\text { Volume } \\
\text { penyimpanan }\end{array}$ & $\begin{array}{l}\text { Semakin besar } \\
\text { semakin bagus }\end{array}$ \\
Harga & Dolar & $\begin{array}{l}\text { Semakin kecil } \\
\text { semakin bagus }\end{array}$ \\
Reliability & $\begin{array}{l}\text { Rata-rata waktu } \\
\text { antar kegagalan }\end{array}$ & $\begin{array}{l}\text { Semakin besar } \\
\text { semakin bagus }\end{array}$ \\
Kecepatan & $\begin{array}{l}\text { Transsaksiper } \\
\text { detik }\end{array}$ & $\begin{array}{l}\text { Semakin besar } \\
\text { semakin bagus }\end{array}$ \\
\hline
\end{tabular}

3. Delighters, sering disebut dengan karakteristik attractive atau exciting. Delighters adalah atribut atau fitur produk kejutan yang menyenangkan untuk konsumen ketika mereka pertama menjumpainya. Akan tetapi, jika delighters tidak ada, konsumen tidak akan 
merasa tidak puas, karena mereka tidak akan menyadari yang kurang dari produk tersebut.

Untuk mengklasifikasikan atribut konsumen, di dalam model kano telah disediakan alat bantu berupa tabel evaluasi kano yang dimana untuk dapat mengisinya menggunakan kuesioner yang akan diisi oleh konsumen. Dalam kuesioner ini terdapat dua bagian untuk setiap pertanyaan, yaitu: (1) apa yang anda rasakan bila fitur ini ada dalam produk, dan (2) apa yang anda rasakan bila fitur ini tidak terdapat dalam produk. Untuk setiap pertanyaan, konsumen dapat menjawab dengan cara yang berbeda-beda. Berdasar jawaban yang diberikan oleh konsumen, maka fitur produk tersebut akan terbagi menjadi 6 kategori, yaitu: $\mathrm{A}=$ Attractive, $\mathrm{M}=$ Must-be, $\mathrm{O}=$ One-dimensional, $\mathrm{I}=$ Indefferent, $\mathrm{R}=$ Reverse, dan $\mathrm{Q}=$ Questionable.

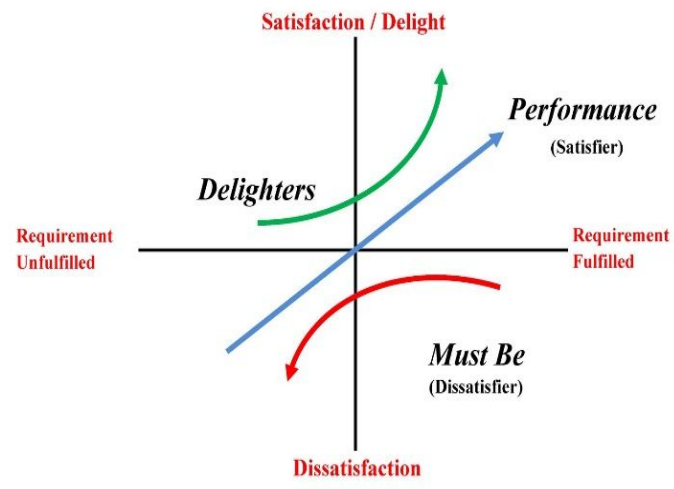

Gambar 1. Diagram Kano (Cohen, 1995)

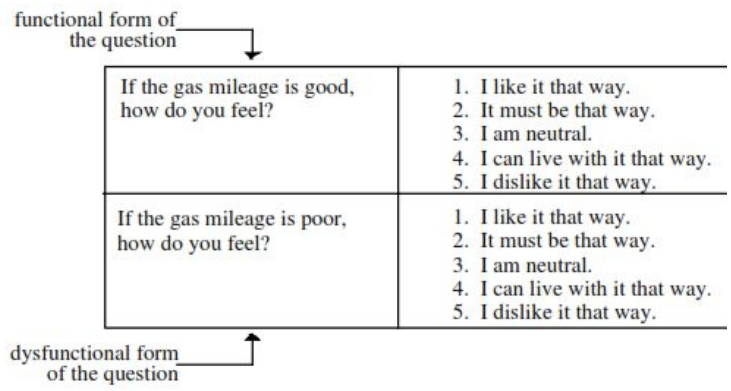

Gambar 2. Contoh pertanyaan pada kuesioner model Kano (Walden, 1993)

Untuk tiga klasifikasi pertama telah dijelaskan sebelumnya, sedangkan untuk indefferent berarti atribut produk ditempatkan sejajar dengan garis horizontal, konsumen tidak akan puas atau juga tidak puas, meskipun produk tersebut fullyfunctional maupun disfunctional. Sedangkan untuk Questionable berarti terdapat kontradiksi pada jawaban konsumen pada pertanyaan yang diajukan dan untuk Reverse berarti penilaian terhadap functional dan disfunctional adalah kebalikan dari yang diinginkan oleh konsumen.

\begin{tabular}{|c|c|c|c|c|c|c|}
\hline \multirow{2}{*}{\multicolumn{2}{|c|}{$\begin{array}{l}\text { Customer } \\
\text { Requirements } \rightarrow\end{array}$}} & \multicolumn{5}{|c|}{ Dysfunctional } \\
\hline & & $\begin{array}{c}1 . \\
\text { like }\end{array}$ & $\begin{array}{c}2 . \\
\text { must-be }\end{array}$ & $\begin{array}{c}3 . \\
\text { neutral }\end{array}$ & $\begin{array}{c}4 . \\
\text { live with }\end{array}$ & $\begin{array}{c}5 . \\
\text { dislike } \\
\end{array}$ \\
\hline \multirow{5}{*}{$\begin{array}{l}\text { Func- } \\
\text { tional }\end{array}$} & 1. like & $\mathrm{Q}$ & A & A & A & $\mathrm{O}$ \\
\hline & 2. must-be & $\mathrm{R}$ & $\mathrm{I}$ & $\mathrm{I}$ & I & $\mathrm{M}$ \\
\hline & 3. neutral & $\mathrm{R}$ & $\mathrm{I}$ & $\mathrm{I}$ & $\mathrm{I}$ & $\mathrm{M}$ \\
\hline & 4. live with & $\mathrm{R}$ & $\mathrm{I}$ & $\mathrm{I}$ & $\mathrm{I}$ & $\mathrm{M}$ \\
\hline & 5. dislike & $\mathrm{R}$ & $\mathrm{R}$ & $\mathrm{R}$ & $\mathrm{R}$ & $Q$ \\
\hline \multicolumn{7}{|c|}{ Customer Requirement is: } \\
\hline & \multicolumn{3}{|c|}{$\begin{array}{l}\text { A: Attractive } \\
\text { M: Must-be }\end{array}$} & \multicolumn{3}{|c|}{$\begin{array}{l}\text { O: One-dimensional } \\
\text { Q: Questionable result } \\
\text { I: Indifferent }\end{array}$} \\
\hline
\end{tabular}

Gambar 3. Tabel evaluasi kano (Walden, 1993)

Menurut Yulismatun dan Singgih (2012), dengan model Kano, kita dapat mengetahui nilai pengaruh masing-masing atribut kebutuhan konsumen pada tingkat kepuasan konsumen yang disimbolkan dengan huruf $\mathrm{S}$, yang berarti semakin besar nilai positifnya, maka atribut keinginan pelanggan akan semakin berpengaruh terhadap kepuasan pelanggan. Nilai $\mathrm{S}$ ini akan berbeda-beda, tergantung preferensi konsumen dan berada dalam rentang antara 0 sampai 1 . Nilai 1 menyatakan pengaruh yang besar terhadap kepuasan konsumen ketika atribut keinginan konsumen itu ditampilkan. Sebaliknya, bernilai 0 menandakan bahwa tidak ada pengaruh anra kepuasan pelanggan dengan atribut keinginan pelanggan yang ditampilkan. Nilai $S$ ini didapatkan dari persamaan berikut:

$$
S=\frac{A+O}{A+O+M+I}
$$

Bila ada pengaruh atribut keinginan pelanggan terhadap kepuasan kepuasan, maka ada pula yang berpengaruh dengan ketidakpuasan konsumen, apabila atribut keinginan konsumen tersebut tidak muncul yang dinotasikan dengan huruf S'. Nilai $S$ ' ini berada pada rentang -1 sampai 0 , dimana nilai -1 berarti pengaruh kuat pada tingkat kepuasan konsumen jika atribut keinginan konsumen tersebut tidak terpenuhi. Dan sebaliknya, nilai 0 menyatakan bahwa tidak ada kaitan antara ketidakpuasan konsumen dengan tidak hadirnya atribut keinginan pelanggan. Adapun nilai S' ini diperoleh dengan persamaan berikut: 


$$
S^{\prime}=-\frac{O+M}{A+O+M+I}
$$

Dengan mengetahui besarnya nilai dari $\mathrm{S}$ dan S', perusahaan dapat melihat atribut kebutuhan pelanggan mana yang perlu diberikan perhatian khusus. Atribut keinginan konsumen yang mendekati nilai -1 perlu diperhatikan karena akan sangat mempengaruhi ketidakpuasan konsumen.

\section{Metodologi}

\section{Pengambilan data}

Penelitian ini diakukan di Kota Semarang dan Yogyakarta, dengan menggunakan responden Fisioterapis dan keluarga pasien sebagai calon konsumen robot rehabilitasi ini yang telah dilakukan dalam penelitian sebelumnya melalui observasi dan wawancara (Mastrisiswadi dan Herianto, 2015). Data awal yang telah diperoleh kemudian digunakan untuk membuat kuesioner Kano yang disebarkan pada 31 orang responden. Kuesioner ini terdiri dari dua pertanyaan untuk tiap atributnya, yaitu pertanyaan positif dan negatif. Hasil dari kuesioner ini nantinya akan digunakan dalam pengolahan data.

\section{Pengolahan data}

Pengolahan data dilakukan dengan merekap hasil kuesioner yang telah didapatkan, kemudian memasukkannya dalam kategori Kano sesuai dengan Kano evaluation table. Kategori yang memiliki nilai terbanyak kemudian dipilih sebagai kategori kano untuk atribut kepuasan pelanggan tersebut. Setelah didapatkan kategori Kano untuk masing-masing atribut, langkah selanjutnya adalah menganalisa dan memberi informasi terkai solusi untuk meningkatkan performansi masing-masing atribut.

\section{HASIL DAN PEMBAHASAN}

Dari penelitian sebelumnya (Mastrisiswadi dan Herianto, 2015) didapatkan variabel terhadap robot rehabilitasi pesien pasca stroke sebagai berikut:

1. Dapat digunakan oleh pasien yang mengalami kesulitan menggenggam.

2. Mudah dipasangkan pada tangan pasien.

3. Terbuat dari material yang aman bagi pasien.

4. Lengan tidak ikut bergerak saat menggunakan robot.

5. Nyaman dipakai oleh pasien.

6. Harga terjangkau.
7. Dapat memasukkan program gerakan dengan mudah.

8. Gerakan dapat divariasikan sesuai kebutuhan pasien.

9. Desain yang sederhana.

10. Mudah untuk dipindahkan (portable).

11. Memiliki desain yang kokoh.

12. Memiliki desain yang menarik.

13. Dapat digunakan di mana saja (tempat tidur, meja, atau kursi roda).

14. Dapat digunakan untuk tangan kanan maupun kiri.

15. Memiliki fungsi lain (dapat juga digunakan untuk kaki, siku, atau jari-jemari).

16. Sistem kontrol robot yang mudah digunakan Atribut-atribut tersebut kemudian diwujudkan dalam pertanyaan positif dan negatif untuk mendapatkan respon terhadap robot rehabilitasi pasien pasca stroke. Hasil pengelompokan dengan menggunakan evaluasi Kano dapat dilihat pada Tabel 3 .

Tabel 3. Tabel evaluasi Kano

\begin{tabular}{cccccccc}
\hline CR & M & A & O & I & Q & R & Grade \\
\hline 1 & 7 & 2 & $\mathbf{1 3}$ & 5 & 3 & 1 & $\mathbf{O}$ \\
2 & 8 & 2 & $\mathbf{1 6}$ & 2 & 3 & 0 & $\mathbf{O}$ \\
3 & 9 & 3 & $\mathbf{1 5}$ & 0 & 4 & 0 & $\mathbf{O}$ \\
4 & 3 & 7 & $\mathbf{9}$ & 5 & 2 & 5 & $\mathbf{O}$ \\
5 & 7 & 2 & $\mathbf{1 8}$ & 2 & 2 & 0 & $\mathbf{O}$ \\
6 & 2 & 5 & $\mathbf{1 9}$ & 3 & 2 & 0 & $\mathbf{O}$ \\
7 & 5 & 5 & $\mathbf{1 6}$ & 3 & 2 & 0 & $\mathbf{O}$ \\
8 & 2 & 3 & $\mathbf{2 0}$ & 3 & 3 & 0 & $\mathbf{O}$ \\
9 & 4 & 6 & $\mathbf{1 2}$ & 6 & 3 & 0 & $\mathbf{O}$ \\
10 & $\mathbf{9}$ & 5 & 7 & 8 & 2 & 0 & $\mathbf{M}$ \\
11 & 9 & 0 & $\mathbf{1 5}$ & 5 & 2 & 0 & $\mathbf{O}$ \\
12 & 3 & 5 & $\mathbf{1 1}$ & 8 & 3 & 1 & $\mathbf{O}$ \\
13 & 5 & $\mathbf{1 0}$ & 8 & 6 & 2 & 0 & $\mathbf{A}$ \\
14 & 4 & 9 & $\mathbf{1 2}$ & 4 & 2 & 0 & $\mathbf{O}$ \\
15 & 4 & 6 & $\mathbf{1 4}$ & 5 & 2 & 0 & $\mathbf{O}$ \\
16 & 11 & 2 & $\mathbf{1 5}$ & 1 & 2 & 0 & $\mathbf{O}$ \\
\hline
\end{tabular}

Dapat dilihat bahwa pada Tabel 3, hanya terdapat 1 atribut yang termasuk dalam kategori must-be, yaitu atribut robot mudah untuk dipindahkan (portable) dan hanya 1 juga yang masuk dalam kategori attractive yaitu robot dapat digunakan dimana saja. Robot mudah untuk dipindahkan terkait dengan desain dari robot, 
pegangan untuk mengangkat, serta bobot dari robot itu sendiri. Sedangkan robot dapat digunakan dimana saja, terkait dengan kemudahan pemaakaiannya, baik di tempat tidur, kursi roda, meja tamu, dan tempat lainnya. Setelah mengetahui masing-masing kategori dari tiap atribut langkah selanjutnya adalah menghitung tingkat kepuasan dan kekecewaan sesuai dengan rumus $\mathrm{S}$ dan S'. Adapun nilai untuk tingkat kepuasan dan kekecewaan terebut dapat dilihatpadaTabel 4.

Tabel 4. Tingkat kepuasan dan kekecewaan

\begin{tabular}{rccc}
\hline No & Grade & $\begin{array}{c}\text { Tk. } \\
\text { Kepuasan }\end{array}$ & $\begin{array}{c}\text { Tk. } \\
\text { Kekecewaan }\end{array}$ \\
\hline 1 & $\mathbf{O}$ & 0,56 & $-0,74$ \\
2 & $\mathbf{O}$ & 0,64 & $-0,86$ \\
3 & $\mathbf{O}$ & 0,67 & $-0,89$ \\
4 & $\mathbf{O}$ & 0,67 & $-0,50$ \\
5 & $\mathbf{O}$ & 0,69 & $-0,86$ \\
6 & $\mathbf{O}$ & 0,83 & $-0,72$ \\
7 & $\mathbf{O}$ & 0,72 & $-0,72$ \\
8 & $\mathbf{O}$ & 0,82 & $-0,79$ \\
9 & $\mathbf{O}$ & 0,64 & $-0,57$ \\
10 & $\mathbf{M}$ & 0,41 & $-0,55$ \\
11 & $\mathbf{O}$ & 0,52 & $-0,83$ \\
12 & $\mathbf{O}$ & 0,59 & $-0,52$ \\
13 & $\mathbf{A}$ & 0,62 & $-0,45$ \\
14 & $\mathbf{O}$ & 0,72 & $-0,55$ \\
15 & $\mathbf{O}$ & 0,69 & $-0,62$ \\
16 & $\mathbf{O}$ & 0,59 & $-0,90$ \\
\hline
\end{tabular}

Apabila nilai tingkat kepuasan mendekati 1, maka dapat diartikan bahwa atribut tersebut semakin mempengaruhi kepuasan robot rehabilitasi. Jika nilai semakin mendekati 0 , berarti atribut tersebut tidak mempengaruhi pengguna. Sedangkan bila tingkat kekecewaan mendekati nilai -1 , itu artinya bahwa pengaruh kekecewaan tersebut akan sangat kuat bila atribut tersebut tidak terpenuhi dan bila mendekati 0 berarti atribut tersebut tidak berpengaruh terhadap kekecewaan pelanggan. Setelah didapatkan nilai tingkat kepuasan dan kekecewaan tersebut.

Dari Tabel 4 dapat dilihat, bahwa nilai tingkat kepuasan tertinggi ada pada atribut ke-enam yaitu harga yang terjangkau. Hal ini berarti semakin terjangkau harga yang ditawarkan akan berpengaruh sangat kuat terhadap peningkatan kepuasan konsumen. Sedangkan atribut dengan nilai tingkat kepuasan konsumen terendah adalah atribut kesepuluh yang masuk dalam kategori must-be, yaitu atribut robot mudah untuk dipindahkan. Artinya atribut ini memiliki pengaruh yang kecil terhadap kepuasan konsumen.

Sedangkan untuk nilai tingkat kekecewaan terbesar ada pada atribut ke-16, yaitu sistem kontrol robot yang mudah digunakan. Hal ini berarti, konsumen akan merasa kecewa bila kontrol robot susah digunakan. Dan untuk tingkat kekecewaan terkecil adalah atribut ke-13 yang tergolong kategori attractive, yaitu atribut dapat digunakan di mana saja. Hal ini berarti bahwa tanpa adanya atribut dapat digunakan di mana saja tidak akan memberikan dampak yang besar terhadap kekecewaan pelanggan.

Setelah selesai melakukan analisa dari Tabel 4, langkah selanjutnya adalah memetakannya ke dalam grafik koefisien kepuasan Kano yang dapat dilihat pada Gambar 4. Dari grafik koefisien kepuasan Kano, dapat dilihat atribut yang kuat maupun lemah terhadap kepuasan dan ketidakpuasan konsumen.

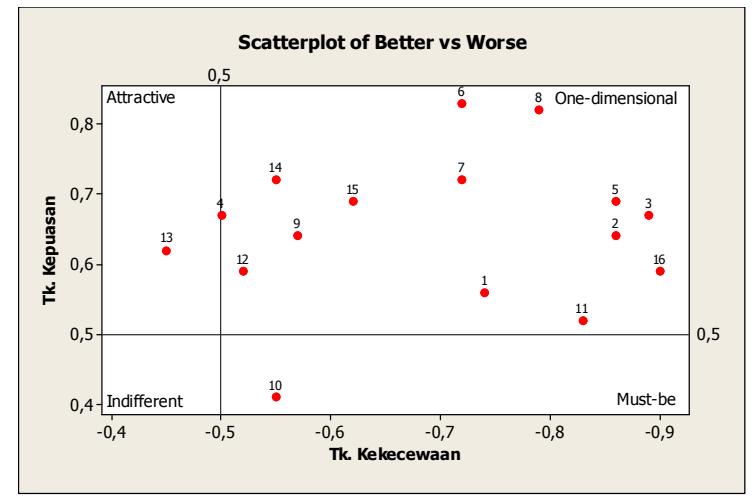

Gambar 4. Grafik koefisien kepuasan Kano

Dari Gambar 4 dapat dilihat bahwa untuk kategori one-dimensional, titik tertinggi adalah pada atribut keenam, yaitu harga yang terjangkau. Adapun titik terendah terdapat pada atribut kesebelas, yaitu robot memiliki desain yang kokoh. Hal ini berarti harga yang terjangkau lebih mempengaruhi kepuasan konsumen dibandingkan dengan desain robot yang kokoh.

\section{SIMPULAN}

Simpulan yang didapat dari artikel ini adalah 
hampir semua atribut termasuk dalam kategori one dimensional, kecuali robot mudah dipindahkan (portable) yang masuk dalam kategori must be dan robot dapat digunakan dimana saja yang termasuk dalam kategori attractive. Atribut harga yang terjangkau merupakan atribut yang mempengaruhi tingkat kepuasan tertinggi konsumen, bila atribut tersebut terpenuhi. Atribut kontrol robot yang mudah merupakan atribut yang mempengaruhi tingkat ketidakpuasan tertinggi konsumen, bila atribut ini tidak dipenuhi.

Untuk pengembangan robot rehabilitasi pasien selanjutnya, perlu mempertimbangkan atribut yang mempengaruhi kekecewaan konsumen yaitu kontrol yang mudah. Desain robot rehabilitasi sebaiknya mempertimbangkan harga yang terjangkau.

\section{DAFTAR PUSTAKA}

Bashar, M.F. 2013. Desain dan Manufaktur Robot Rehabilitasi Anggota Gerak Bawah untuk Pasien Pasca Stroke. Tugas Akhir, Jurusan Teknik Mesin dan Industri, Universitas Gadjah Mada, Yogyakarta.

Cohen, L. 1995. Quality Function Deployment: How to Make QFD for You. Canada: Addison-Wesley Publishing Company.

Cooper, D.R.; Schindler, P.S. 2014. Business Research Methods. New York: Mc Graw Hill.

Donnan, G.A.; Fisher, M.; MacLeod, M.; Davis, S.M. 2008. "Stroke". The Larcet, Vol. 371 (9624), pp. 1612 - 1623.

Eversheim, W. 2009. Innovation Management for Technical Products. Germany: Springer.

Hariandja, J.R.O. 2013. Identifikasi Kebutuhan Akan Sistem Rehabilitasi Berbasis Teknologi Terjangkau Untuk Penderita Stroke di Indonesia. Bandung: Lembaga Penelitian dan Pengabdian kepada Masyarakat, Universitas Parahyangan.

Mastrisiswadi, H.; Herianto, H. 2015. "Identifikasi kebutuhan konsumen robot rehabilitasi pasien pasca stroke dengan menggunakan metode quality function deployment (QFD)". Prosiding Seminar Nasional Teknik Industri. Yogyakarta: Universitas Gajah Mada.

Menteri Kesehatan Republik Indonesia. 2013. Peraturan Menteri Kesehatan Republik Indonesia Nomor 86 Tahun 2013 Tentang Peta Jalan Pengembangan Industri Alat Kesehatan. Jakarta, Indonesia.

Munandar, A.E. 2013. Identifikasi dan Pengembangan Alat Bantu Rehabilitasi Pasien Pasca Stroke. Tugas Akhir. Jurusan Teknik Mesin dan Industri, Universitas Gadjah Mada, Yogyakarta.

Putra, M.M.Y. 2015. Analisis Perencanaan Strategi Pemasaran Robot Alat Bantu Rehabilitasi Pasien Pasca Stroke Berdasar Bobot Kepentingan Faktor Pemasaran dengan Analitycal Hierarchy Process. Tugas Akhir. Jurusan Teknik Mesin dan Industri, Universitas Gadjah Mada, Yogyakarta.
Rachman, Z. 2014. Desain dan Manufaktur Robot Dengan Empat Derajat Kebebasan Sebagai Alat Bantu Rehabilitasi Rentang Pergerakan Sendi Pasif Untuk Lengan. Tugas Akhir. Jurusan Teknik Mesin dan Industri, Universitas Gadjah Mada, Yogyakarta.

Sadhewa, M.A. 2014. Desain dan Manufaktur Robot Rehabilitasi Kaki Kanan Pasien Pasca Stroke dengan Modular Plat untuk Metode Rentang Pergerakan Sendi Pasif. Tugas Akhir, Jurusan Teknik Mesin dan Industri, Universitas Gadjah Mada, Yogyakarta.

Saryanto, W.Y. 2013. Desain dan Manufaktur Robot Rehabilitasi Anggota Gerak Atas Untuk Pasien Pasca Stroke. Tugas Akhir. Jurusan Teknik Mesin dan Industri, Universitas Gadjah Mada, Yogyakarta.

Subhi, M.A. 2015. Analisis Konsep Desain Robot Rehabilitasi Pasca Stroke untuk Pergelangan Tangan dengan Metode Quality Function Deployment (QFD). Tugas Akhir. Jurusan Teknik Mesin dan Industri, Universitas Gadjah Mada, Yogyakarta.

Suwardi, A. 2014. Analisis Rancangan Perbaikan Desain Robot Rehabilitasi Pascastroke Anggota Gerak Atas Dengan Metode QFD dan DFMA. Tugas Akhir. Jurusan Teknik Mesin dan Industri, Universitas Gadjah Mada, Yogyakarta.

Tan, K.C.; Shen, X.X. 2000. "Integrating Kano's model in the planning matrix of quality function deployment". Total Quality Management, Vol. 11(8), pp. 1141 - 1151.

Ulrich, K.T.; Eppinger, S.D. 2008. Product Design and Development. USA: McGraw-Hill.

Wahyudi, S. 2013. Analisis Biomekanika Tangan dan Kaki Manusia Untuk Perancangan Alat Bantu Rehabilitasi Pasien Pasca-Stroke. Tugas Akhir. Jurusan Teknik Mesin dan Industri, Universitas Gadjah Mada, Yogyakarta.

Walden, D.1993. "Kano's methods for understanding customer-defined quality". Center for Quality of Management Journal, Vol. 2(4), pp. 3 - 36.

Yulismatun, F.; Singgih, M.L. 2012. Pengembangan Model Integrasi Kano-QFD Untuk Optimasi Kepuasan Konsumen. Surabaya: Institut Teknologi Surabaya.

Zihni, A. 2014. Desain dan Manufaktur Robot Rehabilitasi Flexion-Extension dan Abduction-Adduction pada Pergelangan Tangan serta Pronation-Supination Pada Lengan Pasien Pasca Stroke. Tugas Akhir. Jurusan Teknik Mesin dan Industri, Universitas Gadjah Mada, Yogyakarta. 